\title{
Коэффициенты межмодовой связи изогнутого маломодового оптического волокна
}

\author{
Д.Е. Прапорщиков" \\ Поволжский государственный университет телекоммуникаций и информатики \\ *E-mail: dep82@mail.ru
}

DOI: 10.31868/RFL2020.211-212

Маломодовые оптические волокна являются одним из перспективных направлений развития волоконной оптики, целью которого является преодоление «нелинейного предела Шеннона» [1-7]. Искажения сигнала при передаче по такому волокну обусловлены в первую очередь совместным действием дифференциальной модовой задержки и межмодовых связей. Последние в свою очередь являются следствием нерегулярностей оптического волокна, которые распределены случайным образом вдоль длины оптического кабеля. Наиболее типичными нерегулярностями оптического волокна строительной длины оптического кабеля являются макро и микроизгибы. Поэтому целью данной работы является расчет коэффициентов связи мод на изгибе маломодового оптического волокна с радиусом изгиба, значительно превышающим диаметр сердцевины волокна.

Расчет коэффициентов связи мод был выполнен для многомодового оптического волокна с усеченным параболическим профилем показателя преломления, вид которого представлен на Рис. 1. В качестве математического аппарата использовались хорошо зарекомендовавшие себя метод приближения Гаусса и метод стратификации. Изогнутый световод заменялся прямым оптическим волокном с эквивалентным профилем показателя преломления. В результате расчетов были получены зависимости коэффициентов связи фундаментальной моды $\mathrm{LP}_{01} \mathrm{c}$ модами $\mathrm{LP}_{11}, \mathrm{LP}_{02}, \mathrm{LP}_{12}$ и $\mathrm{LP}_{03}$ от радиуса изгиба, представленные на Рис. 2.

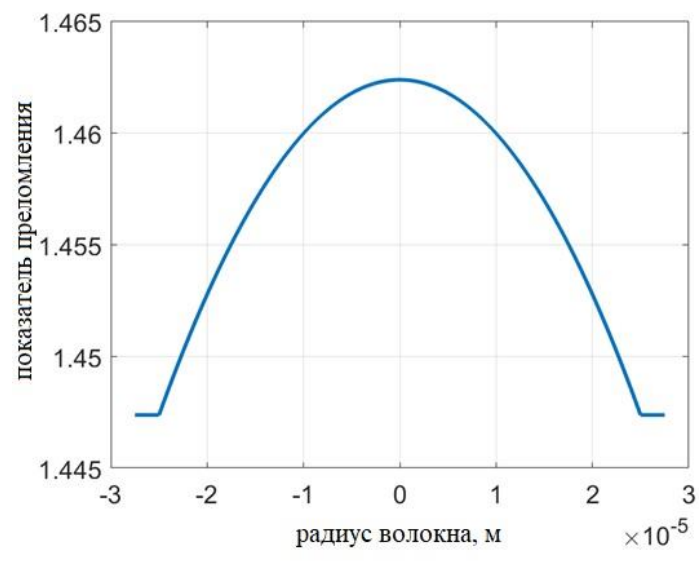

Рис. 1. Профиль показателя преломления исследуемого оптического волокна.

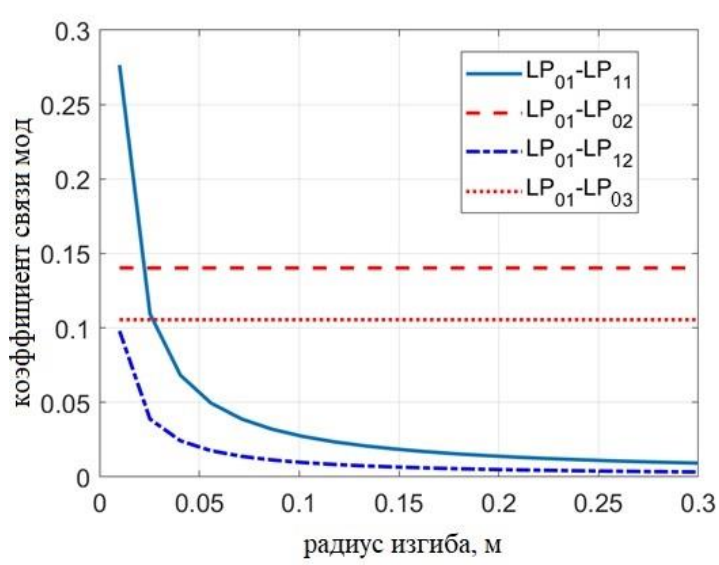

Рис. 2. Зависимости коэффициентов связи мод от радиуса изгиба оптического волокна.

Проведенные расчеты показали, что с уменьшением радиуса изгиба связь мод разных азимутальных порядков резко возрастает. При этом связь мод одного азимутального порядка практически не зависит от радиуса изгиба волокна. Для идеально прямого оптического волокна связь между модами разного азимутального порядка отсутствует, но даже слабая кривизна оптического волокна приводит к ее возникновению. 


\section{Литература}

[1] P.P. Mitra, J.B. Stark, Nature 411, 1027-1030 (2001)

[2] J.M. Kahn, P.H. Keang, Nature 411, 1007-1010 (2001)

[3] R.J. Essiambre, G.J. Foschini, et al, Physical review letters 101(16), 163901-1-4 (2008)

[4] R.J. Essiambre, G.J. Foschini, et al,

https://www.researchgate.net/publication/241159582_Capacity_Limits_of_FiberOptic_Communication_Systems

[5] A.D. Ellis, J. Zhao, D. Cotter, Journal of lightwave technology 28(4), 423-433 (2010)

[6] R.J. Essiambre, G. Kramer, et al, Journal of Lightwave Technology 28(4), 662-701 (2010)

[7] A. Amphawan, Optical Engineering 50(10), 102001-1-102001-6 (2011) 